\title{
EVALUATION OF COSMOS BIPINNATUS CAV., COSMOS SULPHUREUS CAV. AND RUDBECKIA HIRTA L. VARIETIES FOR DIRECT SOWING ON FLOWER BEDS
}

\author{
T. Kut'ková, P. Vaida
}

Received: September 13, 2012

\begin{abstract}
KUŤKOVÁ, T., VAIDA, P.: Evaluation of Cosmos bipinnatus Cav., Cosmos sulphureus Cav. and Rudbeckia hirta L. varieties for direct sowing on flower beds. Acta univ. agric. et silvic. Mendel. Brun., 2012, LX, No. 8, pp. 145-154

There were concentrated and evaluated 21 varieties of Rudbeckia hirta L., 12 varieties of Cosmos bipinnatus Cav. and 9 varieties of Cosmos sulphureus Cav. for the establishment of flower mixtures by direct sowing in the garden and landscape design. Very poor emergence rate of all varieties of Rudbeckia hirta L. in all repetitions confirmed the impossibility of their cultivation by direct sowing. All evaluated varieties of Cosmos bipinnatus Cav. demonstrated the possibility of direct sowing cultivation, but high varieties can not be recommended for direct sowing on beds due to uneven height, late beginning of flowering and susceptibility to lodging. All evaluated varieties of Cosmos sulphureus Cav. were characterized by good seed emergence rate, balanced and reliable flowering, solid and orderly growth, even in the case of higher varieties. All evaluated varieties can be recommended for cultivation.
\end{abstract}

Cosmos bipinnatus Cav., Cosmos sulphureus Cav., Rudbeckia hirta L., direct sowing, flower mixtures, landscape architecture

Except of classically designed green space, current garden and landscape design is looking for cost-effective and time saving technologies of establishment and maintenance of plant communities, often inspired by nature. One such possibility is the flower herb mixtures establishment by direct sowing.

Herb mixtures may consist of only annuals, so they are designed for one growing season, or can be mixed from perennials and affect the composition for several years. The combination of perennial herbs and annuals is also possible - in the first year after planting, annuals give the mixture rapid effectiveness, necessary dynamics and colour effect. Many foreign institutions and authors deal with the solution of the topic (DUNNETT, 1999, 2003; DUNNETT, HITCHMOUGH, 2004; DUTHWEILER, 2010; WILSON, 2006; WALZ, 2007; EPPEL-HOTZ，2006，2007，2008; KINGSBURY, 2004). Timeliness of the topic is also confirmed by experiences of local authors (NOVOTNÁ,
2009, 2010, 2011; STRAKOVÁ, STRAKA, 2009; STRAKOVÁ, 2011; JONGEPIEROVÁ, BÁBKOVÁ HROCHOVÁ, 2008; NIKODÉMOVÁ, BRADNA, 2010; KUŤKOVÁ, 2004, 2009a, 2009b, 2010; KUŤKOVÁ, ČERNÝ LOŠONSKÁ, 2009; ČERNÝ LOŠONSKÁ, KUŤKOVÁ, 2010a, 2010b).

One of the problems addressed in the preparation of sowing herb mixtures is the selection of suitable taxa. The non-native species and their varieties may be also used, in addition to original botanical herb species, when applying mixtures in urban environment. The varieties of intensively cultivated species may vary in their properties and effect in composition. Some varieties of Cosmos bipinnatus Cav., C. sulphureus Cav. and Rudbeckia hirta L. have been already tested in previous years (KUŤKOVÁ, 2010) and showed very good results, and therefore the focus was to assemble the widest possible assortment of varieties and to compare them one another for use in mixtures together with other flowers on beds established by direct sowing. 


\section{MATERIALS AND METHODS}

The field trial on the plot of experimental garden of the Faculty of Horticulture of the Mendel University in Brno was based in 2011 to evaluate varieties of Cosmos bipinnatus Cav., C. sulphureus Cav. and Rudbeckia hirta L.

Site characteristics: an experimental area is situated at an altitude of 176 meters, according to QUITT (1971) it belongs to the warm region with a total rainfall during the growing season from 350 to $400 \mathrm{~mm}$.

Establishment of trial plot and care for it: the trial plot was situated in full sun in a range of irrigation water. The plot was prepared for the experiment by standard horticultural technology used for growing flowers or vegetables. Supply of soil nutrients and $\mathrm{pH}$ of the habitat show the soil analysis conducted on May 4, 2011 by chemical laboratory in Velké Bílovice (see Tab. II). Prior to trial establishment neither in its course was the trial plot fertilized with mineral fertilizers. Preceding crop residues of celery and chard from 2010 were ploughed into the soil. Soils are loamy with crumb to nutty structure, permeable, with higher sand content (36.5\%) of fraction 0.05-0.01.

The trial was established on April 11, 2011. A total of 12 varieties of Cosmos bipinnatus Cav., 9 varieties of Cosmos sulphureus Cav. and 21 varieties of Rudbeckia hirta L. were assembled. Each variety of the genus Cosmos Cav. was sown in a row in 50 pieces of seeds in three repetitions, except for the varieties 'Picotee', 'Double Click Mix' and 'Pied Piper Red', which were sown only in the lst repetition due to unavailability of seeds. The results are only informative. Each variety of Rudbeckia hirta L. was sown in 100 seeds in three repetitions. The rows were spaced $60 \mathrm{~cm}$. The seeds were sown by hand in windless weather in shallow furrows, then covered with soil and gently roll flat.
II: Soil analysis results

\begin{tabular}{ccc}
\hline Parameter & Unit & Measured value \\
\hline $\mathrm{N}_{\mathrm{NH} 4}$ & $\mathrm{mg} / \mathrm{kg}$ & 3.20 \\
$\mathrm{~N}_{\mathrm{NO} 3}$ & $\mathrm{mg} / \mathrm{kg}$ & 9.63 \\
$\mathrm{~N}_{\mathrm{NO} 2}$ & $\mathrm{mg} / \mathrm{kg}$ & 0.01 \\
$\mathrm{~N}_{\text {anorg. }}$ & $\mathrm{mg} / \mathrm{kg}$ & 12.84 \\
$\mathrm{P}$ & $\mathrm{mg} / \mathrm{kg}$ & 115 \\
$\mathrm{~K}$ & $\mathrm{mg} / \mathrm{kg}$ & 440 \\
$\mathrm{Mg}$ & $\mathrm{mg} / \mathrm{kg}$ & 645 \\
$\mathrm{Ca}$ & $\mathrm{mg} / \mathrm{kg}$ & 4360 \\
$\mathrm{pH}$ & & 8.06 \\
\hline
\end{tabular}

After seed germination and at the beginning of the vegetation, the rows were cleared of weeds and loosened with hoe and inter-rows with cultivator. The plants were not hoed after their establishment. During the drought were sown plots irrigated.

\section{Rated taxon characteristics}

Taxon emergence rate: sum of the individuals emerged from the ground in row. Seedlings were counted on May 30, 2011, seven weeks from sowing, when all the seeds germinated and the plants could be reliably identified in a row and counted.

Height: in centimetres with increments of $5 \mathrm{~cm}$; to determine the height, the height of most of individuals (75\%) in a row was determinative; measurements were carried out more or less at regular weekly intervals using a wooden metre rule. The objective was to compare the reached height of taxa at the time of the full flowering (flowering stage 4) with variety data provided by its supplier.

Two groups of varieties were included in the verification tests of the Cosmos bipinnatus Cav. species: - lower with compact growth - varieties of the Sonata group;

I: Meteorological data for 2011 for the trial site

\begin{tabular}{|c|c|c|c|c|c|c|c|c|c|}
\hline \multirow{2}{*}{ Month } & \multicolumn{5}{|c|}{$\begin{array}{c}\text { Temperature } \\
\left({ }^{\circ} \mathbf{C}\right)\end{array}$} & \multirow{2}{*}{$\begin{array}{c}\text { Relative } \\
\text { humidity } \\
(\%)\end{array}$} & \multicolumn{2}{|c|}{$\begin{array}{c}\text { Rainfall } \\
\text { (mm) }\end{array}$} & \multirow{2}{*}{$\begin{array}{l}\text { Sunshine } \\
\text { (hrs) }\end{array}$} \\
\hline & Max & Min & Average & $\begin{array}{c}\text { Normal } \\
1961-1990\end{array}$ & $\begin{array}{c}\text { Ground } \\
\text { min. }\end{array}$ & & Aggreg. & $\begin{array}{c}\text { Normal } \\
1961-1990\end{array}$ & \\
\hline 1. & 12.3 & -12.2 & -0.1 & -1.9 & -15.2 & 85.5 & 29.2 & 24.3 & 34.2 \\
\hline 2. & 11.3 & -11.7 & -0.5 & 0.3 & -15.7 & 80.0 & 2.1 & 23.9 & 103.3 \\
\hline 3. & 19.1 & 0.0 & 5.7 & 4.4 & -13.7 & 63.1 & 48.2 & 24.8 & 191.4 \\
\hline 4. & 26.8 & -0.4 & 12.7 & 9.7 & -3.1 & 62.0 & 52.0 & 34.7 & 202.3 \\
\hline 5. & 28.5 & -0.4 & 15.2 & 14.5 & 0.0 & 64.9 & 47.7 & 57.7 & 296.9 \\
\hline 6. & 31.0 & 9.4 & 19.7 & 17.5 & 4.1 & 66.2 & 80.6 & 66.4 & 242.1 \\
\hline 7. & 32.9 & 10.8 & 19.5 & 19.1 & 0.0 & 67.6 & 79.1 & 59.8 & 203.0 \\
\hline 8. & 35.5 & 6.6 & 20.4 & 18.4 & 4.5 & 69.0 & 27.2 & 50.0 & 255.4 \\
\hline 9. & 31.5 & 5.7 & 17.0 & 14.6 & 2.3 & 69.9 & 4.3 & 37.3 & 239.9 \\
\hline 10. & 27.2 & -3.8 & 9.3 & 9.3 & -6.1 & 76.2 & 42.8 & 32.7 & 126.4 \\
\hline 11. & 16.1 & -5.9 & 2.9 & 4.0 & -9.5 & 77.4 & 1.2 & 41.4 & 80.1 \\
\hline 12. & 11.1 & -7.3 & 2.9 & 0.0 & -11.3 & 78.4 & 18.4 & 26.7 & 31.9 \\
\hline Year & 23.6 & -0.8 & 10.4 & 9.2 & -5.3 & 71.7 & 432.8 & 479.7 & 2006.9 \\
\hline
\end{tabular}


- higher with the loosened growth - other varieties. and of the Cosmos sulphureus Cav. species:

- lower with compact growth - varieties of the Cosmic group and the 'Limara Lemon' variety;

- higher with the loosened growth - other varieties.

Flowering: taxa evaluation took place more or less at regular weekly intervals from opening the first flowers to September 13, 2011. Flowering stages:

1 - visible buds, opening of the first flowers;

2 - beginning of flowering - less than $1 / 3$ of flowering plants or flowers;

3 - full flowering - more than $1 / 3$ and less than $1 / 2$ of flowering plants or flowers;

4 - full flowering - $1 / 2$ of flowering plants or flowers and less than $1 / 3$ of faded plants;

5 - finishing flowering - more than $1 / 3$ of withered plants or flowers;

6 - finishing flowering - more than $1 / 2$ of withered plants or flowers;

7 - finishing flowering - more than $2 / 3$ of withered plants or flowers.

Aesthetic effect of taxon in composition: besides the flowering, the reached size, the development of leaves and fruits and aging of individuals is also important to express the aesthetic effect of taxon in the compositional unit:
$\mathrm{P}$ - positive effect in composition - a taxon, with its size, colour of leaves and partial flowering (flowering stage 1, 2, 3 or 5), has a positive effect in the composition;

VP - very positive (flowering stage 4, lush green leaves, the beginning of fruit creation);

PN - partially negative (flowering stage 6, dried ovaries begin to appear on plants, leaves partially change the colour and dries, aboveground parts of plant begin to die;

$\mathrm{N}-$ negative (flowering stage 7, dried ovaries dominate, flowers appear only sporadically in small quantities, most of the above-ground biomass is dried).

The length of aesthetic effect of taxon in composition (in weeks) is the sum of the positive, very positive and partially negative effect and it provides the total time during which the taxon presence in the compositional unit (most often in bed) is acceptable.

The emergence rate and plant height was statistically evaluated with Statistica 10 software. The individual varieties were compared using Games-Howell analysis of variance. To compare the heights of individual varieties were calculated the weighted averages of heights, taking into account the frequency of evaluation in the $4^{\text {th }}$ flowering stage.

III: The number of RUDBECKIA HIRTA L. variety seedlings emerged from the ground

\begin{tabular}{|c|c|c|c|c|c|}
\hline \multirow{3}{*}{ No. } & \multirow{3}{*}{ Variety name } & \multirow{3}{*}{ Variety origin } & \multirow{2}{*}{\multicolumn{3}{|c|}{$\begin{array}{c}\text { The number of seedlings emerged } \\
\text { from the ground }\end{array}$}} \\
\hline & & & & & \\
\hline & & & $1^{\text {st }}$ & $2^{\text {nd }}$ & $3^{\text {rd }}$ \\
\hline 1. & 'Toto Rustic' & Benary & 0 & 0 & 0 \\
\hline 2. & 'Toto Lemon' & Benary & 0 & 0 & 0 \\
\hline 3. & 'Toto Gold' & Benary & 0 & 0 & 0 \\
\hline 4. & 'Cherry Brandy' & Benary & 0 & 0 & 0 \\
\hline 5. & 'Maya' & Benary & 0 & 0 & 0 \\
\hline 6. & 'Goldilock' & Benary & 1 & 0 & 0 \\
\hline 7. & 'Autumn Colors' & Benary & 0 & 0 & 0 \\
\hline 8. & 'Rustic' & Benary & 0 & 0 & 0 \\
\hline 9. & 'Tiger Eye Gold' & Syngenta Czech s.r. o. & 0 & 0 & 0 \\
\hline 10. & 'Gloria Daisy' & Hem Zaden Bv. & 0 & 0 & 0 \\
\hline 11. & 'Corona' & Benary & 0 & 0 & 0 \\
\hline 12. & 'Cordoba' & Benary & 0 & 0 & 1 \\
\hline 13. & 'Marmelade' & Benary & 0 & 0 & 0 \\
\hline 14. & 'Má radost' & Seva-Seed Valtice & 0 & 2 & 0 \\
\hline 15. & 'Sonora' & Benary & 0 & 0 & 0 \\
\hline 16. & 'Cappuccino' & Tézier & 0 & 0 & 0 \\
\hline 17. & 'Prairie Sun' & Benary & 0 & 0 & 0 \\
\hline 18. & 'Hvězda z Kelvedonu' & Semena Veleliby & 2 & 0 & 0 \\
\hline 19. & 'Cherokee Sunset' & Thompson \& Morgan & 0 & 0 & 0 \\
\hline 20. & 'Denver Daisy' & Benary & 0 & 0 & 0 \\
\hline 21. & 'Gloriosa Double Daisy' & Benary & 0 & 0 & 0 \\
\hline
\end{tabular}




\section{RESULTS AND DISCUSSION}

\section{Taxon emergence rate}

The varieties of the evaluated taxa were sown on April 11, 2011. The first seedlings of Cosmos Cav. varieties already appeared a week after sowing. Counting of individuals emerged from the ground was made on May 30, 2011.

Only a tiny amount of individuals of the 21 sown varieties of Rudbeckia hirta, each of 100 seeds and three repetitions, emerged from the ground (see Tab. III), therefore it was not possible to continue in a trial. Most of the available literature (PRŮCHA, 1966; MACHOVEC, 1983; KASPAROVÁ, VANĚK, 1993; RYBKOVÁ, HAAGER, 2002) states the need to pre-grow the Rudbeckia hirta L. species. The experiences with direct sowing of Rudbeckia hirta L. 'Prairie Sun' from the years 2008 and 2009, when out of 50 pieces of sown seeds repeatedly emerged from the ground only five seeds (KUŤKOVÁ, 2010), were the reason for re-verification of this rich varietal taxon. Rudbeckia hirta L. brings a long-term and very significant colour composition effect, so the possibility of its use by direct sowing would be very valuable. As the results imply, emergence rate of Rudbeckia hirta L. varieties is very low, unreliable, which was confirmed in three repetitions, and therefore can not be recommended for flower mixtures establishment by direct sowing.

The emergence rate of Cosmos bipinnatus Cav. and Cosmos sulphureus Cav. varieties illustrate Tab. IV, Fig. 1 and 2 The highest emergence rate of Cosmos bipinnatus Cav. was recorded in the 'Sonata White' variety, the average emergence rate was 41.3 pieces, i.e. $83 \%$. Statistically highly significantly different were varieties 'Dazzler' and 'Sonata White Premium', provable differed from one another were varieties 'Dazzler' with 'Sonata White', 'Sonata Pink Blush', 'Sonata Carmine'. The results further show that all varieties of the Sonata group showed relatively balanced seed germination in all repetitions, with high average value in the range 66-83\%. 'Dazler' and 'Sensation' varieties with the emergence rate of $34 \%$ and $37.4 \%$ lagged behind varieties mentioned above and the emergence rate in individual repetitions was very uneven. 'Double Click Mix', 'Pied Piper Red' and 'Picotee' varieties were sown only in the first repetition, so their result is for informational purposes only.

The highest average emergence rate of Cosmos sulphureus Cav. species was recorded in the 'Žlutý' variety -42.7 pieces, i. e. $85.4 \%$. The variety achieved

IV: The number of COSMOS BIPINNATUS Cav. and COSMOS SULPHUREUS Cav. variety seedlings emerged from the ground

\begin{tabular}{|c|c|c|c|c|c|}
\hline \multirow{3}{*}{ No. } & \multirow{3}{*}{ Variety name } & \multirow{3}{*}{ Variety origin } & \multicolumn{3}{|c|}{$\begin{array}{l}\text { The number of seedlings emerged } \\
\text { from the ground }\end{array}$} \\
\hline & & & \multicolumn{3}{|c|}{ Repetition: } \\
\hline & & & $1^{\text {st }}$ & $2^{\text {nd }}$ & $3^{\text {rd }}$ \\
\hline \multicolumn{6}{|c|}{ COSMOS BIPINNATUS CAV. } \\
\hline 1. & 'Sonata Mix' & Rudy Raes Bloemzaden N.V. & 37 & 28 & 32 \\
\hline 2. & 'Sonata White' & Rudy Raes Bloemzaden N.V. & 44 & 40 & 40 \\
\hline 3. & 'Sonata Pink Blush' & Rudy Raes Bloemzaden N.V. & 34 & 31 & 34 \\
\hline 4. & 'Sonata Carmine' & Rudy Raes Bloemzaden N.V. & 37 & 41 & 40 \\
\hline 5. & 'Sonata Carmine Premium' & PanAmerican Seed & 41 & 34 & 30 \\
\hline 6. & 'Sonata White Premium & PanAmerican Seed & 43 & 37 & 39 \\
\hline 7. & 'Dazzler' & Sempra Veltrusy & 19 & 19 & 13 \\
\hline 8. & 'Radiance' & Semena Veleliby & 0 & 0 & 0 \\
\hline 9. & 'Sensation' & Seva-Seed Valtice & 25 & 8 & 23 \\
\hline 10. & 'Double Click Mix' & Kiepenkerl & 29 & - & - \\
\hline 11. & 'Pied Piper Red' & Thompson \& Morgan & 20 & - & - \\
\hline 12. & 'Picotee' & Thompson \& Morgan & 29 & - & - \\
\hline \multicolumn{6}{|c|}{ COSMOS SULPHUREUS CAV. } \\
\hline 1. & 'Cosmic Yellow' & Benary & 36 & 30 & 40 \\
\hline 2. & 'Cosmic Orange' & Benary & 48 & 37 & 34 \\
\hline 3. & 'Cosmic Red' & Benary & 40 & 40 & 30 \\
\hline 4. & 'Limara Lemon' & Benary & 43 & 34 & 34 \\
\hline 5. & 'Red Crest' & Seva-Seed Valtice & 37 & 32 & 20 \\
\hline 6. & 'Lemon Crest' & Seva-Seed Valtice & 30 & 40 & 33 \\
\hline 7. & 'Sunset' & Seva-Seed Valtice & 4 & 4 & 2 \\
\hline 8. & 'Carpet Mix' & Hem Zaden Bv. & 33 & 33 & 33 \\
\hline 9. & 'Žlutý' & Seva-Seed Valtice & 42 & 45 & 41 \\
\hline
\end{tabular}




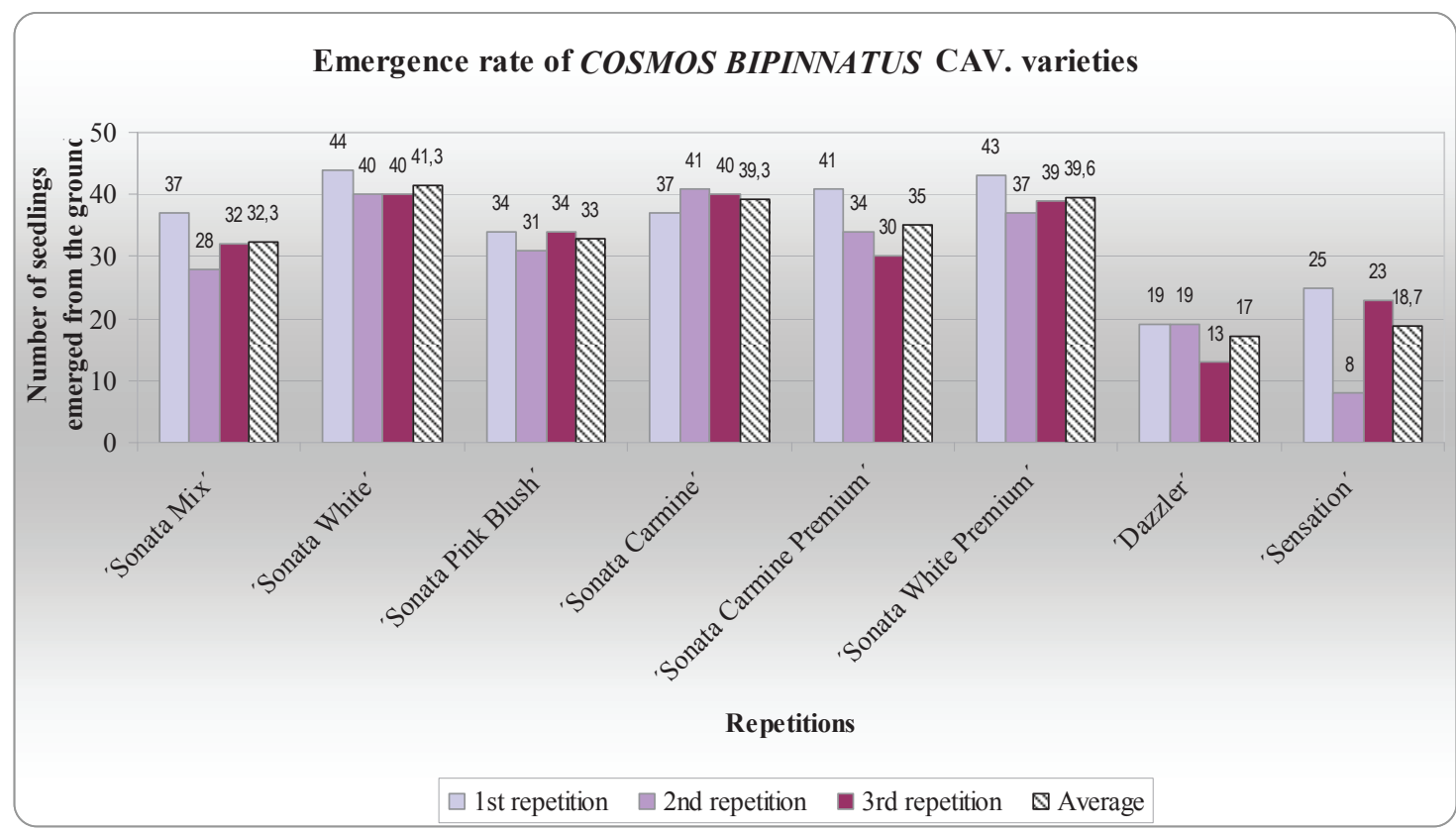

1: Emergence rate of COSMOS BIPINNATUS Cav.

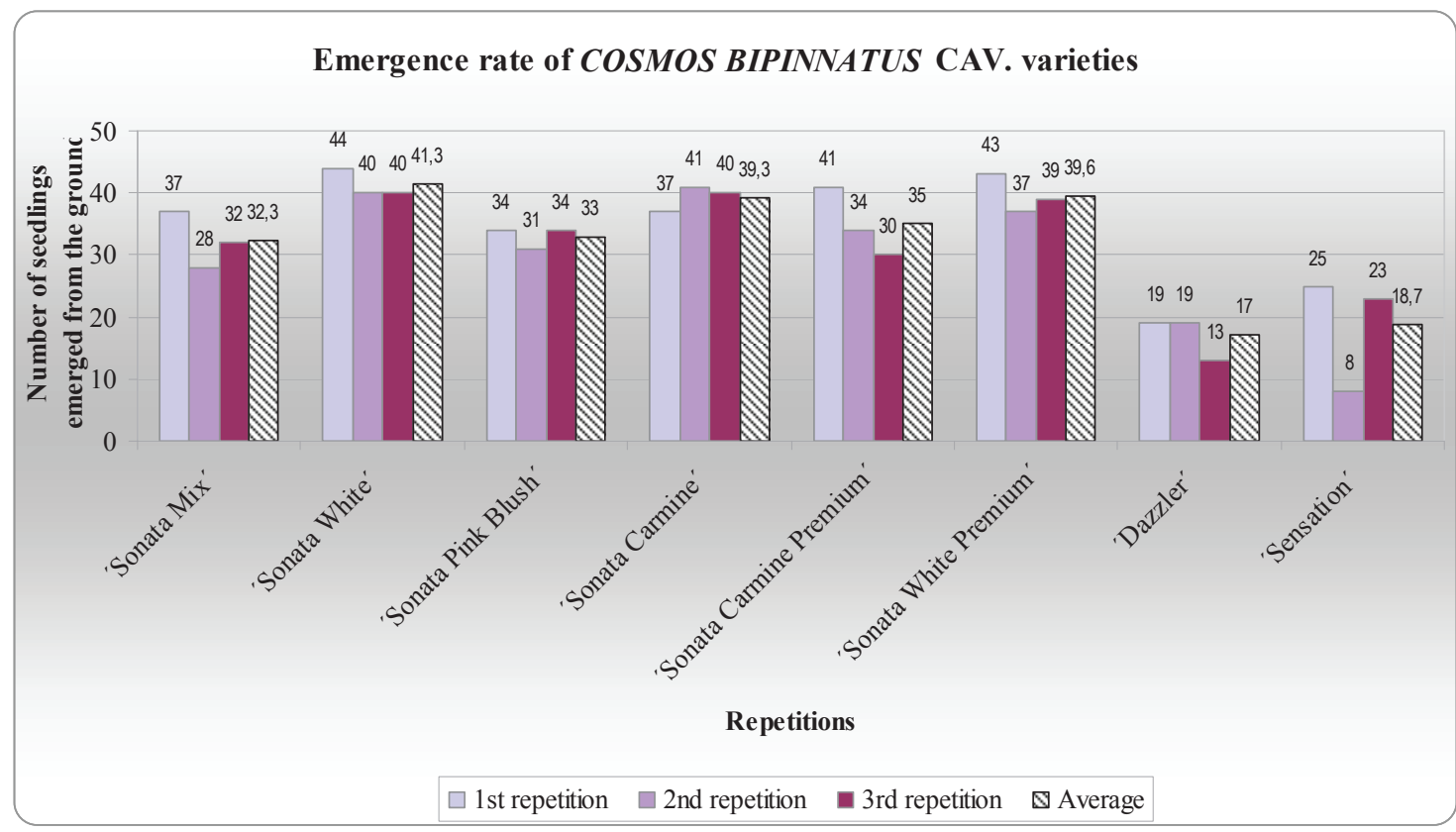

2: Emergence rate of COSMOS SULPHUREUS Cav.

very balanced emergence rate in all repetitions, too. The emergence rate in other varieties ranged between 59.4 \% ('Red Crest') and $79.2 \%$ ('Cosmic Orange'). The variety 'Sunset' showed the considerably lowest emergence rate in all three repetitions. Its average emergence rate was very low in all three repetitions and in no case came close to emergence rate of $30 \%$ in 2009 (KUŤKOVÁ, 2010). That could be caused by poor seed germination in 2011. Statistical evaluation also proved highly significantly difference between 'Sunset' and 'Žlutý' varieties. Other varieties ranged in statistical analysis in similar homogenous groups which showed similar values to each other.

\section{Taxon height in the full flowering stage}

Along with flowering was measured at regular intervals the taxon height, too. The reached taxon height at the peak of effect - in the full flowering stage - is important in terms of flower mixtures creation. Reached average height of varieties in this stage shows the Tab. V.

The highest average height of the group of compact 'Sonata' varieties reached the 'Sonata White', namely 
V: Average height of Cosmos bipinnatus Cav. and Cosmos sulphureus Cav. varieties in the flowering stage 4

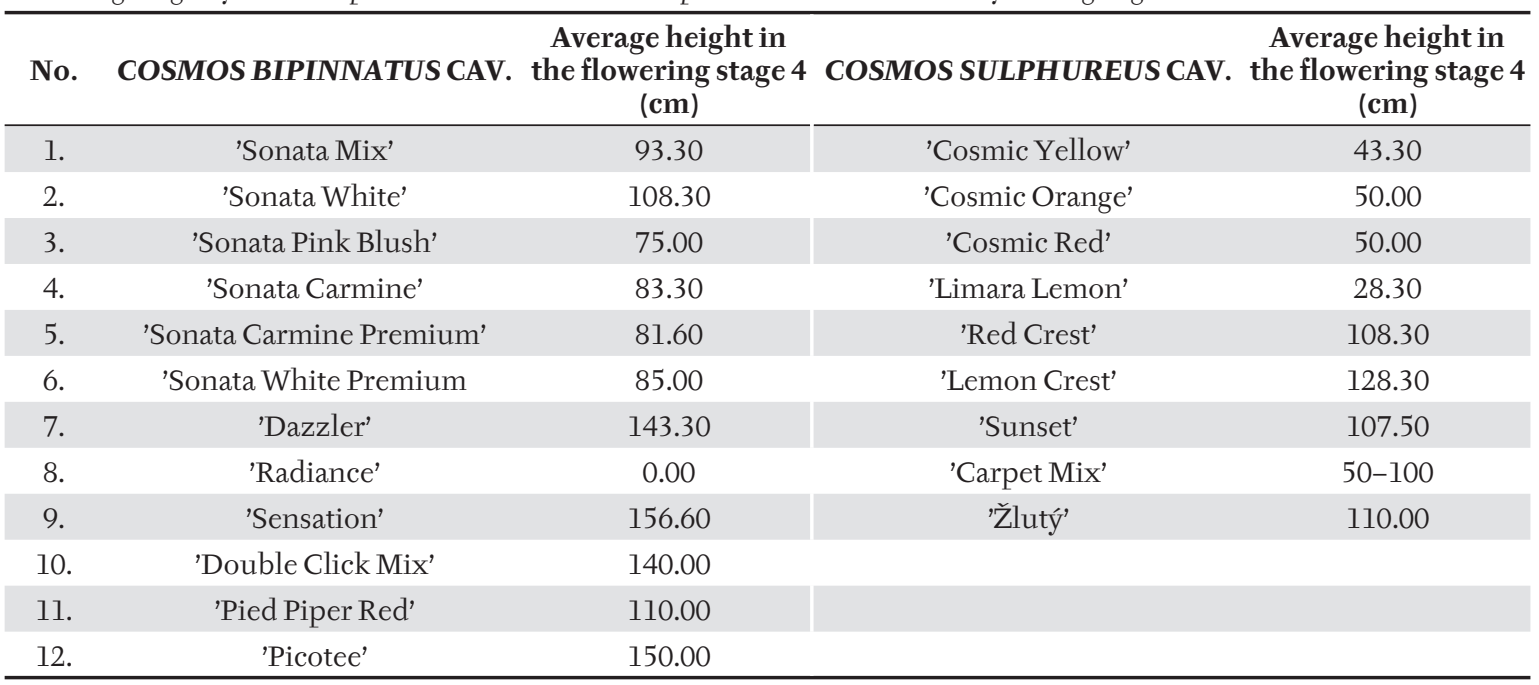

VI: Statistical evaluation of compared varieties

\begin{tabular}{|c|c|c|c|c|c|c|c|c|c|}
\hline Evaluated variety & 'Sunset' & $\begin{array}{l}\text { 'Cosmic } \\
\text { Yellow' }\end{array}$ & $\begin{array}{l}\text { 'Cosmic } \\
\text { Orange' }\end{array}$ & $\begin{array}{c}\text { 'Cosmic } \\
\text { Red' }\end{array}$ & $\begin{array}{l}\text { 'Limara } \\
\text { Lemon' }\end{array}$ & $\begin{array}{c}\text { 'Red } \\
\text { Crest' }\end{array}$ & $\begin{array}{c}\text { 'Lemon } \\
\text { Crest' }\end{array}$ & $\begin{array}{l}\text { 'Carpet } \\
\text { Mix' }\end{array}$ & 'Žlutý' \\
\hline \multicolumn{10}{|l|}{ 'Sunset' } \\
\hline \multicolumn{10}{|l|}{ 'Cosmic Orange' } \\
\hline \multicolumn{10}{|l|}{ 'Cosmic Red' } \\
\hline 'Red Crest' & & $* *$ & & & & & & & \\
\hline 'Lemon Crest' & & $* *$ & & & & & & & \\
\hline 'Carpet Mix' & & $*$ & $* *$ & $* *$ & $* *$ & & & & \\
\hline 'Žlutý' & & $* *$ & & & $* *$ & & & $*$ & \\
\hline
\end{tabular}

Legend:

** = statistically highly significant difference

* = statistically significant difference

$108.3 \mathrm{~cm}$. In the third repetition this variety grew up to height of $120 \mathrm{~cm}$. This significantly exceeded the height of $60 \mathrm{~cm}$, declared by supplier for varieties of this group. The variety 'Sonata Pink Blush' came the most close to this value, with the average height of $75 \mathrm{~cm}$ in the full flowering stage. This variety showed statistically highly significantly difference with variety 'Dazzler'. As significantly different was evaluated the variety 'Dazzler' with 'Sonata Carmine Premium', 'Sonata White Premium', and 'Sensation' variety with 'Sonata Pink Blush'. All varieties of the Sonata group hold very well their shape, stems were strong enough, varieties did not fallen down. Other varieties belonging to category of mountain varieties were characterized by unordered and unbalanced growth, the highest variety 'Sensation' with its average height of $156.6 \mathrm{~cm}$ felt down in the first repetition.

The group of compact Cosmos varieties of Cosmos sulphureus Cav. reached relatively balanced average heights. The differences among low varieties were not statistically significant. The lowest height was of 'Cosmic Yellow', namely $43.3 \mathrm{~cm}$, the other two varieties of this group reached the same average height of $50 \mathrm{~cm}$. Again, the measured height differed from data provided by supplier which declare height of $30 \mathrm{~cm}$ for this group. The 'Limara Lemon' variety with height of $20 \mathrm{~cm}$ declared by supplier reached the average height of $28.3 \mathrm{~cm}$ when measured. The result of statistical analysis of evaluated varieties is showed in Tab. VI.

The height of higher varieties ranged from $107.5 \mathrm{~cm}$ ('Sunset') to $128.3 \mathrm{~cm}$ ('Lemon Crest'). The absolutely greatest height was measured in the variety 'Lemon Crest' in three repetitions, namely $140 \mathrm{~cm}$.

\section{Taxon flowering}

The course of flowering of each variety is recorded in Tab. VII that shows at which flowering stage the taxon was in the time of evaluation. In Tab. VII is also possible to deduce how long from time of sowing the taxon begins to flower, total flowering time of taxon and consequently to state the period of positive effect in composition unit. 
VII: COSMOS BIPINNATUS Cav. flowering

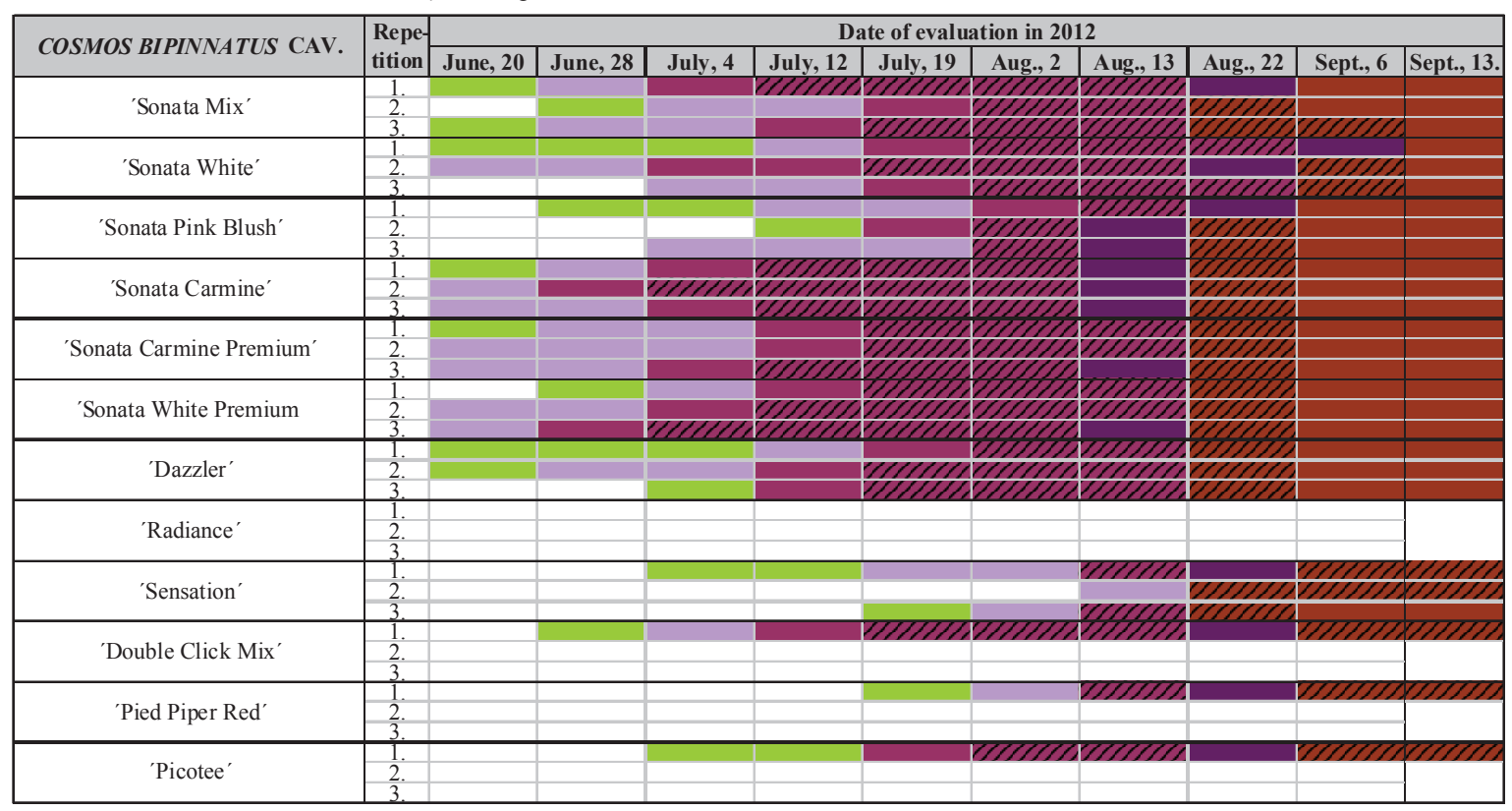

Legend - flowering stage:

1. visible bud, opening of the first flowers

2. beginning of flowering - less than $1 / 3$ of flowering plants or flowers

3. full flowering - more than $1 / 3$ and less than $1 / 2$ of flowering plants or flowers

4. full flowering $-1 / 2$ of flowering plants or flowers and less than $1 / 3$ of faded plants

5. finishing flowering - more than $1 / 3$ of withered plants or flowers

6. finishing flowering - more than $1 / 2$ of withered plants or flowers

7. finishing flowering - more than $2 / 3$ of withered plants or flowers

It is obvious from the Tab. VII that the varieties of Sonata group are much earlier than other evaluated varieties. On average they began to flower in $9^{\text {th }}$ week after sowing. The exception was 'Sonata Pink Blush' variety that began to flower 14 days later. Their total flowering time is 12 to 13 weeks. In the last flowering stage (7) outweighed the negative visual characteristics of taxon, so the length of the taxon positive effect in composition in terms of flowering is shorter and for most evaluated varieties finished in late August. This finding means that Sonata varieties are not suitable varieties for being sown in monocultures, but it is better to combine them with other annuals, which covers drying above-ground parts of plant until time of flower bed liquidation. Very valuable property of evaluated taxa is lush green, softly parted leaf. The varieties with their fine texture, shape and lush colour of leaf have therefore a positive effect in composition as early as two to three weeks before appearance of the first flowers. High varieties can not be recommended for flower mixtures for bed establishment by direct sowing due to their height imbalance, occasional falling down, very uneven begin of flowering and late start to flowering. 'Picotee', 'Double Click Mix' and 'Pied Piper Red' varieties are interesting enlivening of colours and shapes with possible another usage in garden and landscape design.
It is obvious in Tab. VIII that Cosmos sulphureus Cav. varieties are about 14 days later than the compact Sonata group varieties. The first began to flower 'Red Crest', 'Lemon Crest' and 'Žlutý' varieties, namely 11 weeks after sowing what is approximately the same as the term declared by KUŤKOVÁ (2010) for 'Sunset' and 'Carpet Mix' varieties. The 'Žlutý' variety has been flowering a week shorter than the Crest group varieties. The flowering time was shifted about 14 days to September, compared with the Sonata group varieties. The 'Sunset' variety can not be objectively compared with the above varieties given the very small number of emergenced plants. There were only slight differences in the group of Cosmic and 'Limara Lemon' compact varieties, as shown in Tab. VIII. All evaluated Cosmos sulphureus Cav. varieties kept shape well and as well as Cosmos bipinnatus Cav. varieties acted positively with their overall appearance as early as two to three weeks before flowering.

High varieties had experienced an extensive branching of thin but sufficiently rigid stalks, very heavy with flowers, showing no lodging. Most of the leaves is concentrated in the lower parts of stems and therefore higher varieties, unlike the compact varieties, have a light, airy effect and can be fully recommended for use in flower mixtures established by direct sowing. 
VIII: COSMOS SULPHUREUS Cav. flowering

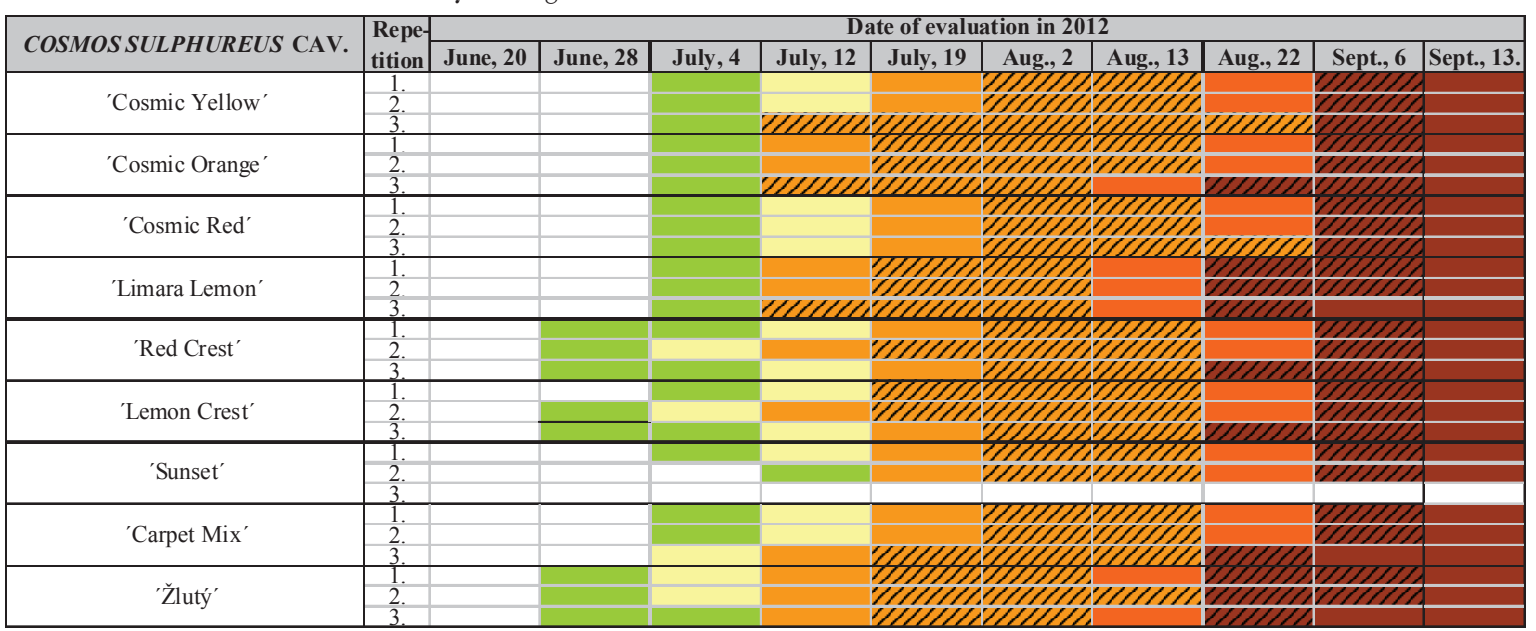

Legend - flowering stage:

1. visible bud, opening of the first flowers

2. beginning of flowering - less than $1 / 3$ of flowering plants or flowers

3. full flowering - more than $1 / 3$ and less than $1 / 2$ of flowering plants or flowers

19. full flowering $-1 / 2$ of flowering plants or flowers and less than $1 / 3$ of faded plants

5. finishing flowering - more than $1 / 3$ of withered plants or flowers

finishing flowering - more than $1 / 2$ of withered plants or flowers

finishing flowering - more than $2 / 3$ of withered plants or flowers

\section{SUMMARY}

Flower herb mixtures with representation of annuals, established by direct sowing, may be an alternative to demanding annual flower beds established by classical gardening method. They are used both in private gardens and in public greenery in the urban area. Nowadays, we can more and more often meet abroad the realizations of this type of vegetation element in the urban greenery. In the Czech Republic lacks enough experience with their implementation.

Positive experience with the possibility of growing by direct sowing of Rudbeckia hirta L., Cosmos bipinnatus Cav. and Cosmos sulphureus Cav. species (KUŤKKOVÁ, 2010) and their high aesthetic value were the impulse to establish the trials to evaluate and compare selected characteristics of available varieties for cultivation in flower mixtures established by direct sowing.

There were concentrated 21 varieties of Rudbeckia hirta L., sown in 100 seeds in three repetitions, and 12 varieties of Cosmos bipinnatus Cav. and 9 varieties of Cosmos sulphureus Cav. The varieties of Rudbeckia hirta L. genus in either repetition failed to demonstrate a good emergence rate, it was not possible to continue the trial and the Rudbeckia hirta L. varieties can not be recommended for flower mixtures establishment by direct sowing.

The emergence rate of Cosmos bipinnatus Cav. varieties was high, ranged from 66-83 \% in the compact varieties and $34 \%$ and $37.4 \%$ in the higher varieties. High emergence rate (59.4-85.4\%) was reported for all evaluated Cosmos sulphureus Cav. species with the exception of the'Sunset' variety. Evaluated varieties of both species of the Cosmos Cav. genus have been flowering for 12-13 weeks; Cosmos bipinnatus Cav. varieties were two weeks earlier. The total period of positive effect of taxa in compositional unit is 1518 weeks.

All the compact Cosmos bipinnatus Cav. varieties of the Sonata group and all the evaluated Cosmos sulphureus Cav. varieties can be recommended for use in flower beds established by direct sowing.

\section{Acknowledgement}

The article was based on the support of the project No. DF11P01OVV019 - Landscape architecture's methods and tools for spatial development, that meets the thematic priority TP 1.4 of the Programme of Applied Research and Development of the National and Cultural Identity (in short, "NAKI"), funded by the Ministry of Culture of the Czech Republic. 


\section{REFERENCES}

ČERNÝ LOŠONSKÁ, I. a KUŤKOVÁ, T., 2010a: Vplyv biodegradovatelných mulčovacích materiálov na vývoj ciel'ových i nežiadúcich taxonov v okrasných kvetinových záhonoch. In: Vliv abiotických a biotických stresoru na vlastnosti rostlin 2010. Praha: ČZU v Praze, v.v.i. Praha Ruzyně, s. 236-240. ISBN 978-80-213-2048-2.

ČERNÝ LOŠONSKÁ, I. a KUŤKOVÁ, T., 2010b: Okrasné letničkové záhony zakladané priamym výsevom - nové postupy a technológie a ich vplyv na ciel'ové taxony. In: Venkovská krajina. Brno: Česká společnost pro krajinnou ekologii, regionální organizace CZ-IALE, s. 94-98. ISBN 978-8087154-43-4.

DUNNETT, N., 1999: Annuals on the loose. In: The Garden, 124, 3: 168-171. ISSN 03085457.

DUNNETT, N., 2003: Wiesen aus enjärigen Pflanzenarten. GRÜNFORUM.LA, 5: 10-11.

DUNNETT, N. and HITCHMOUGH, J., 2004: The dynamic landscape: design, ecology, and management of naturalistic urban planning. London: Spon Press, 332 p. ISBN 04-152-5620-8.

DUTHWEILER, S., 2010: Aussaatversuche mit Sommerblumenmischungen für das öffentliche Grün. Fachtagung „Stauden Pflanzen \& Säen im öffentlichen Freiraum" 19. November 2010, Universität für Bodenkultur, Wien.

EPPEL-HOTZ, A., 2006: Ansaat von Sommerblumenflüchen auf unterschiedlichen Trägermaterialien. Würzburg/Veitschöchheim: Bayerische Landesanstalt für Weinbau und Gartenbau Abteilung Landespflege, S. 6.

EPPEL-HOTZ, A., 2007: Ansaat pflegeleichter Sommerblumenflächen. In: Stadt und Grün. BerlinHannover: Patzer Verlag, 54, 8: 42-47. ISBN 09489770.

EPPEL-HOTZ, A., 2008: Pflegeleichte Annuaellenwiesen etablieren. In: Gartenpraxis. Stuttgart: Eugen Ulmer, 34, 3: 28-31. ISBN 0341-2105.

JONGEPIEROVÁ, I. a BÁBKOVÁ HROCHOVÁ, M., 2008: Louky Bílych Karpat: Grasslands of the White Carpathian Mountains. Veselí nad Moravou: ZO ČSOP Bílé Karpaty, 461 s. ISBN 978-80-9034446-4.

KASPAROVÁ, H. a VANĚK, V., 1993: Letničky a dvouletky. 2. vyd., Praha: Brázda, 159 s. ISBN 80209-0247-3.

KINGSBURY, N., 2004: Contemporary overview of naturalistic planting design. In: DUNNETT, N. - HITCHMOUGH, J. The Dynamic Landscape. London: Spon Press, p. 58-96. ISBN 0-415-256208.

KUŤKOVÁ, T., 2004: Letničky z přímých výsevů - inspirace a potěšení. In: Management sídelní zeleně. Luhačovice: Společnost pro zahradní a krajinářskou tvorbu, s. 72-75. ISBN 80-9029107-4.

KUŤKOVÁ, T., 2009a: Letničky pro přímý výsev I. Zahradnictví, LXXXIII, 5: 35-38. ISSN 1213-7596.

KUŤKOVÁ, T., 2009b: Letničky pro přímý výsev II. Zahradnictví, LXXXIII, 8: 28-29. ISSN 1213-7596.

KUŤKOVÁ, T., 2010: Letničky z přímých výsevů a květinový záhon. In: Acta horticulturae et regiotecturae: vedecký ćasopis prezahradnictvo, krajinné inžinierstvo, architektúru a ekologiu. Nitra: Slovenská poInohospodářská univerzita, 13, mimoriadne číslo, s. 31-36. ISSN 1335-2563.

KUŤKOVÁ, T. a ČERNÝ LOŠONSKÁ, I., 2009: Letničkové záhony z přímých výsevů - sortimenty, směsi, technologie. [CD-ROM]. In: Dny zahradní a krajinářské tvorby: rostliny-diagnostický znak oboru?!. 1. vyd., Praha: Společnost pro zahradní a krajinářskou tvorbu, s. 87-98. ISBN 978-8086950-07.

MACHOVEC, J., 1983: Sadovnickékvétináriství. Skripta. Praha: SPN.

NIKODÉMOVÁ, Z. a BRADNA, B., 2010: Jak vypèstovat kvétnatou louku. 1. vyd., Praha: Grada, 86 s. ISBN 978-80-247-2755-4.

NOVOTNÁ, K., 2009: Letničky z přímých výsevů v Brně. In: Zahrada - Park - Krajina.

NOVOTNÁ, K., 2010: Letničky z přímých výsevi̊ v Brně rok poté. In: Zahrada - Park - Krajina, č. 4, s. 30-31. ISSN 1211-1678

NOVOTNÁ, K., 2011: Přímé výsevy letniček rozkvetou města? In: Zahrada - Park - Krajina. XXI, č. 4, s. 32-34

PRŮCHA, J., 1966: Letničky a dvouletky. 1. vyd. Praha: SZN.

QUITT, E., 1971: Klimatické oblasti Československa. Brno: Academia. Studia Geographica 16, GÚ ČSAV. $73 \mathrm{~s}$.

RYBKOVÁ, R. a HAAGER, J., 2002: Nejhezčí letničky našich zahrad. Praha: Ottovo nakladatelství - Cesty, 221 s. ISBN 80-718-1539-X.

STRAKOVÁ, M., 201l: Květnaté louky s letničkami ve veřejné zeleni. Svét zeleně, 2011, 2, 3-4: 14-15.

STRAKOVÁ, M. a STRAKA, J., 2009: Využití květnatých luk v zahradní a krajinářské architektuře. Rozbor problematiky z pohledu fytocenologického, protierozního, nutričního a agrotechnického. In: Dny zahradní a krajinárské tvorby. Luhačovice 25.-27. 11. 2009. [CD-ROM] s. 71-76. ISBN 978-80-86950-07.

WALZ, U., 2007: Farbe in die Stadt. In: Garten und Landschaft. München: Callwey Verlag, 117, 5: 8-11. ISSN 0016-4720.

WILSON, M., 2006: Sowing fields of gold. In: The Garden. London: Royal Horticultural Society, 131, 4: 250-253.

Address

doc. Ing. Tatiana Kutková, CSc., Bc. Pavel Vaida, Ústav biotechniky zeleně, Mendelova univerzita v Brně, Valtická 337, 69144 Lednice, Česká republika, e-mail: kutkova@zf.mendelu.cz, vaida@zf.mendelu.cz 
